\title{
Analysis of Consumer Psychology Subject To Daily Time and Level of Education in Indonesia
}

\author{
Kadek Ayu Dani Astari, Komang Santhi Arsa, Lovina Claudia Iristianty, and Suhadi Riandana
}

\begin{abstract}
This brief paper will discuss about consumer behavior in terms of daily time and level of education. Consumer behavior in here is endogenous variable that is determined by the daily time and level of education. Authors look at nowadays situation that understanding the consumer behavior is an important task for the company, especially the marketing part. Because, it is one of the components which form the basis in the preparation of the marketing mix that can be displayed by the company. Then authors focus on the daily time and level of education as factors to explain that consumer behavior. The research used direct observation approach and interview measuring the condition of consumer psychology in effect of their consuming behavior. Authors discussed from the point of view of direct testimonies about level of satisfaction of buying behavior of consumer. Besides that, authors also use method of literature review to strengthen analysis. Then, authors would expect this brief paper able to be a recommendation for companies in Indonesia in formulating effective and efficient marketing strategies, and able to be recommendations for consumers and government as well.
\end{abstract}

Index Terms-Consumer behavior, consumer psychlogy, daily time, level of education.

\section{INTRODUCTION}

Nowadays, the development of economy sector in Asia grew very rapidly, which makes few countries in Asia become new markets or emerging markets, including Indonesia. In the middle of the world economic crisis, Indonesia became the country with high economic growth rate, one of the top five in the world. It can be seen through advancement of capital city of Indonesia, Jakarta, identifies itself as a megapolitan city with high economic potential. Supported by a large population, growing economy, stable political issues, strengthen Indonesia's position as the center of the ASEAN economies. Companies both local and multinational in Indonesia should be able to prepare themselves and become a whiz in this situation, not only preparing for what products will be produced and sold, but also preparing a strong marketing strategy and able to devise the right marketing mix.

Understanding the consumer behavior is an important task for the company, especially the marketing part. It is because marketing is one of the components that form the basis in the preparation of the marketing mix, how companies make the products, pricing, place, and how promotion strategy that can be displayed by the company.

Manuscript received October 25, 2013; revised December 26, 2013.

The authors are with the Universitas Indonesia (University of Indonesia) Indonesia (e-mail: suhadi.rindana@gmail.com, lovina.ciristianty@gmail.com).
The marketers are trying to understand the buying behavior of consumers so that they can offer greater satisfaction to the consumer. Nevertheless some degree of consumer dissatisfaction will be still existed. Some marketers are not applying good marketing concepts so that they are not consumer-oriented and do not view customer satisfaction as a primary goal. Furthermore, the tool to analyze consumer behavior is uncertain. The marketers may not be able to accurately define what exactly things can satisfy the consumers. Even if the marketers know the factors that increase customer satisfaction, they are not necessarily able to meet these factors.

Undoubtedly, consumers considered to be the most valuable asset for any business. Without their support, a business cannot exist. In contrast, in order to make the business run well, consumers can also be useful agents that help our business grow. More than that, they would recommendit to friends and their relations.

In this paper, authors would like to discuss specifically about consumer behavior in terms of daily time and level of education. Consumer behavior in here is endogenous variable that is determined by the daily time and level of education. Later, authors would expect this brief paper able to be a recommendation for companies in Indonesia in formulating effective and efficient marketing strategies.

\section{A. Formulation of the Problems}

Background of above problem, can pull a thread formulation of the problem as follows:

1) What are the main factors that affect the most of consumer perspective in consuming goods and services?

2) How is the level of customer satisfaction with the current economic condition? Especially in Jakarta?

3) What actions the firms should take level of due to fulfill the desire of consumer regarding the psychology due to level of education?

4) How is the role of government itself in this regard?

\section{B. Method}

This research used direct observation approach and interview measuring the condition of consumer psychology in effect of their consuming behavior. These models are used to analyze and find the key factors of which affect the consumer behavior due to daily time and their own level of education. These whole methods expected to map and categorized the general occurrences of consumer behavior. On the other hand, these models are also designed to help firms to determine the desire and needs of consumer and conduct a systematic evaluation to satisfy customers. Authors discussed from the point of view of direct testimonies about level of satisfaction of buying behavior of consumer. Besides that, authors also use method of 
literature review to strengthen analysis, which then summarized into a single instruction, direction at once that will lead to the solution and recommendation regarding the topic.

\section{BASIS THEORY}

\section{A. Scarcity and Choice Theory}

In meeting their needs, consumers face scarcity that occurred, whether it was the scarcity of goods and services and the scarcity of economic and financial resources to fulfill their needs. Scarcity is a condition when the human needs are limited by the available resources. Because of the scarcity, consumer must choose which requirements they must satisfyied advance and which needs that can be delayed. Each consumer will generally satisfy the primary needs which are a fundamental necessity for every human life, consisting of clothing, housing and food. Then, after the primary needs are met, consumers can switch to meet their secondary and tertiary needs with the remaining budget available.

Scarcity and consumer choice that should be made in the consumption of goods, as result, companies need to think harder about what to be produced. It is because the company must be able to be the top choice of consumers for the consumption of goods and services, so that company can gain a competitive position in the market. By understanding the concept of scarcity and consumer choices, the company can produce goods and services according to what things be desired and needed by consumers. Then, consumers can make purchase decisions on the products produced by the company in accordance with the budget that is owned by the consumer.

\section{B. Consumer's Satisfaction Theory}

Once the consumer doing the consumption of goods and services, a reaction or response from the consumers occurred about the products they consume. The reaction may indicate satisfaction or dissatisfaction of consuming goods. Satisfaction arises from a feeling when goods consumed are equal or exceed their expected benefits from consuming these goods. Meanwhile, dissatisfaction arises if consumers feel any benefit gained from consuming a product is below their expectations.

According Budiastuti (2002) [1], there are many factors that can affect the level of customer satisfaction, which in general can be classified into:

\section{1) Quality of products or services}

Consumers will be satisfied if their evaluation results indicate that the product or service quality is used. Consumer perceptions of product or services quality affected by two things: the fact or the real quality of products and communications services companies in promoting their products, especially by advertising.

\section{2) Quality of care}

This aspect plays an important role in the service industry. Customers will be satisfied if they gain a good experience or service as expected.

\section{3) Emotional factor}

Consumers, who feel proud and confident that everyone else was amazed to consumers if the consumers choose products that already have a view "exclusive products", tend to have a higher level of satisfaction.

\section{4) Price}

Price is an important aspect, but the most important in determining, the quality to achieve customer satisfaction.

\section{Consumer's Behavior}

Consumer's behavior is a process and activity when a person deals with searching, choosing, buying, using, and evaluating products and services due to fulfilling his meeds.

According to James F. Engel - Roger D. Blackwell - Paul W. Miniard in Saladin (2003:19) [2] there are three factors which affect consumer's behavior:

1) Environment's influence consists of culture, social class, family and situation. Consumers live in a complex environment, therefore it is very important to understand the effect of environment which can build up or impede the individual in taking their consumption decision.

2) The individual's difference and influence, consists of learning and memory, personality and self concept, motivation and involvement, attitude, and life style. Individual's difference is an interpersonal factor which empower and influence behavior.

3) Phychological process, consists of information processing, learning, attitude and behavior alteration.

\section{Consumer's Phychology}

Consumer's decision is influenced by consumer himself as an individual. Solomon (2009) [3] said that individual internal dynamics which eventhough is not seen by others, is really important by everyone. Involved in it is the perception process that is how an individual absorb and interpret all informations about the products and others, learning process that is how an individual keep the information and how the information will complete the prior knowledge,the individual reasons or motivation to absorb spesific information and how culture's value affects what somebody is doing, and how the attitude is formed and changed as well as affecting consumption's behavior.

Consumer's psychology is a relationship between a product's creation and its usage opportunity by individualswith psychological processes which involves understanding about psychological process within the consumer's as an individual and group, psychological aspects which can be considered in marketing strategy/products' distribution, marketing research in context of psychology. Schiffman and Kanuk (2007) [4] said that consumer's psychology consists of basic concept of psychology which decides individual's behavior and influencing consumption's behavior. The factors of consumer's psychology are motivation, perception, learning, and consumer's attitude.

\section{1) Motivation}

According to Hawkins et al. (2007) [5] motivation is the strength which activate somebody to do an activity or things which directs to the behavior desired. Mowen and Minor (2002) [6] said that motivation is activated by (a) stimulus, both from inside and outside the consumers to change their behavior because there is a difference between the desired 
situation with the actual one which can cause needs; (b) introduction of needs, consists of expressive needs that is a wish to fulfill social requirement and esthetic in order to maintain self concept of an individual and utilitarian needs that is a wish to finish basic problems; (c) motivation, that is a factor which build in an affective condition (another emotion and psychology) which affects individual's involvement level, (d) behavior on purpose based, that is an action which is done to lighten somebody's needs, (e) consumer's insentive for example, the products, services, information, and even somebody else whom the consumers believe can satisgy their needs.

Basically motivation can be divided into :(a) rational motif, is when human being act rationally to consider and choose the multi purpose alternatives. In the context of marketing, consumers choose the products based on objective characteristics, for example size, price, weight, etc.; (b) emotional motif, that is a selection based on subjective And personal characteristics for example: pride, fear, feeling and status. This is correlated with sekunder needs or even tersier needs. In conclusion, every single act done by the consumers hss its own readon.

\section{2) Perception}

Perception is a process where people choose, organise, and interpret stimulus into information which can give a description about something meaningful (Schiffman and Kanuk, 2007) [7]. Perception is something started from interaction between two factors: (a) stimulus factors, which are physical, object characteristics for example size, colour, shape, and weihht. The outlook of a product in terms of its wrapping and characteristics is able to create stimulus on somebody's sensor; (b) individual factors, that is the personal experience of an individual, the main motivation to buy, and wish from the individual himself toward a product or service.

Viewing the definition of perception above, can be seen that perception is a three step process that is through a sequence started with exposure, caring, and ended up with interpretation. Exposure happens when a stimulus is accepted by the consumers. Caring is resources delivery by an individual to a stimulus. Interpretation is the meaning given by an individual to a stimulus accepted. Therefore marketers need to do various efforts to make every step in the process run properly. A marketer needs to make his stimulus (an advertisement, for example) is acceptable by the consumers (exposed), next the consumers will give attention to the stimulus, finally what is interpreted by the consumers toward the marketer's stimulus fits the marketer's wish. In other word, through his sensor, the consumer can make a perception whether a profuct is good or not.

\section{3) Learning}

Learning is a process where people can get knowledhe and experience about buying and consuming which they can apply for their future behavior (Schiffman and Kanuk, 2007) [8]. Basically there are two approahes in consumers' learning. Those are: (a) behavioral approach that is a learning process happened as a consumer's response toward a stimulus or consumer's environment; (b) cognitive approach where learning is viewed as a problem's solution.

In behavioral approach there are two concepts which are knwon and practiced widely in marketing, those are clasical conditioning and instrumental conditioning. Clasical conditioning happened when a stimulus which produces responses is matched with the stimulus which can not produce responses repeatedly, and then next the stimulus which can not produce responses at first but can produce responses afterwards because has been associated with the productive stimulus. This becomes a basic why a wellknown brand can introduce its new product easily and succed. The second concept is instrumental conditioning which explains why somebody is eager to do something which is beneficial or giving positive outcomes to himself and avoid doing something which gives negative outcomes.

In cognitive approach, the consumers observe others' behavior which gives positive effects for their behavior. In this approach an individual observes others and act as if he is the one he is observing. A learning process tends to be happened from his indirect experience.

\section{4) Attitude}

Àttitude is an overall evaluation toward a seen or heard object, which then gives a conclusion about the related object (Solomon, 2009) [9]. A general discussion given could be good or bad, beneficial or not, and positive or negative to the evaluated object. In marketing, generally an individual, who has a positive attitude toward a product or brand, has bigger possibility to buy that product.

\section{E. Buying Decision Making}

Consumers's behaviors are the things which motivate the consumers to make buying decision. Decision making is an activity which directly involved in getting and using the products offered. According to Kotler (1997:162) [10] there are five steps in decision making.

\section{1) Analysis or needs recognition}

Buying process is started with needs recognitiom, where the buyers recognize a problem or need. The buyers feel the difference between the reality and the desiref situation.

\section{2) Information seeking}

When a consumer's motivation is strong and the desired product is in his reach, he possibly would buy it. If not, the consumers could keep the needs in their memory or seek the information related to the needs. The consumer can get the information from some resources, some of them are (Kotler (1997:163) [11] private resource, commersial resource, public resource, and experience resource.

\section{3) Alternative evaluation}

Marketing should know about alternative evaluation, how the consumers process the information until the brand selection. Spesific basic concept helps to explain consumers' evaluation process. First, we consider that evety consumer sees the product as a collection of products' attribute. For the camera, the attribute involves picture quality, simplicity in it's' usage, the camera's size, the price, and another attribute. Second, the consumers will give different level of important meaning toward different attribute deals with unique needs. Third, the consumers develop a bunch of brand faith about where the position of any brand in any attribute. Fourth, consumers' products satisfaction wish would vary in different attribute level. Fifth, the consumers 
have different attitude through some evaluation procedure. There are some consumers who use more than one evaluation procedure, depend on the consumers and buying decision.

\section{4) Buying decision}

In evaluation step, the consumers make brand level and build a desire to buy. Generally, the consumers buying decision is to buy the most favorite brand, but two factors may appear between the desire to buy and the decision to buy.

\section{5) Post buying behavior}

The consumers take forward action after buying based on satisfaction or not. The buyers feel satisfy or not toward a transaction lays on relationship between the consumers' wish and the benefit taken from the product. If the product is out ef expectation, the costumers will feel unsatisfy. If the product is beyond expectation, the consumers will fell very satisfied.

\section{DISCUSSION}

\section{A. General Factors Affecting Purchasing Behavior}

There are several factors that affect the most the purchasing behavior of consumer, as follows:

\section{1) Level of Education}

Level of education indirectly affects consumer's perspective in choosing and purchasing the goods or services. The higher a person's level of education, the level of consumption is even higher .Because when someone had a high level of education, they are no longer obliged to not only meet food and drinking needs but also meet the needs of information, better social interaction, and also the recognition from others about their existence. Often the costs required to meet this need is far greater than the cost of meeting the needs to eat and drink.

People, with high level of education, tend to be more selective in their purchases. That is because the higher a person's education level, the more needs that must be fulfilled and the higher the costs required to meet these needs, which causes consumers should choose the goods or services which must be fulfilled first . In addition, most people who have a high level of education are very concerned about the quality and price before making a purchase decision. A society with a low level of education,tend to not really concerned about quality whenpurchase goods or services, but they tend to look for goods or services at the lowest price so they can meet all the needs that they have. Another case with, for those whit high level of education, are usually concerned about the quality of goods or services and will compare the price with the quality obtained. That is because they also think about the long term use of goods or services.

\section{2) Life style}

Life style is the way of life that determines and shows people choices to use the time, money and energy, and reflect the values, tastes, and preferences. Lifestyle is about how someone running what the concept itself that is determined by the characteristics of individuals, formed since birth and along the social interaction as long as they live in their life cycles.

Mowen and Minor [12] stated that it is important for company to segment the market by identifying the life style through the patterns of buying a product consistently, the use of consumer time and involvement in various activities. Life style that is desired by someone influences their buying behavior, and will further influence or even change the life style oft he individual.

There are two factors that affect someone's lifestyle that come from the individual (internal) and external factors. Internal factors are attitude, experience, observation, personality, self-concept, motives and perceptions. While external factors are reference group, family, and social class (Nugraheni, 2003:17) [13].

\section{3) Social class}

All human societies display social layers which is sometimes form like a caste system in which members of different castes assume certain roles and they can not change the caste membership. And more frequent, social layer misshaped social class. Social class is the relatively permanent and last long in a society, which is arranged in a hierarchy and the membership of this social class has value, interest and similar behavior. Social class is not determined by a single factor, such as income, but measured from a combination of income, employment, education, wealth and other variables.

Social class is important for company. Consumers buy various products because these products are favored by members of their own social class or a higher class, and the consumer may avoid a variety of other products because they feel these products are products of a lower class.

Social class was also important for the producers because producers can distinguish theirtarget market, whether to a higher status or lower status in selling their products. Lifestyle of the upper layer must be different from the lifestyle of the middle and bottom layers. With the money,many upper layer of society are usually more consumerist in their purchases and can buy luxury goods that the price are expensive, while for the lower middle class, luxury goods is a waste that they would do if forced to buy it.

The influence of the social classes on consumer behavior would seem from the purchase of daily needs. There are differences of behavior in buying daily necessities either primary or only as an ornamental in the social class. For social class of higher status would purchase famous branded goods, in a special place and has expensive price. As for the social class from lower status, will purchase the goods in accordance with their ability and in the ordinary places. The social class of consumers that can be widely accepted and may be the best measure of social class looks from job, education and income. Company take advantage of the social classes in issuing its products, which is visible from a set price and quality of products provided.

\section{B. Today's Consumer's Satisfaction Level in Jakarta}

According to the Nielsen Global Survey of Consumer Confidence and Spending Intentions [14], Indonesian Consumer Confidence Index recorded the highest global score of 120 in the second quarter of 2013. This figure is down 4 points from the previous quarter and 26 points 
higher than the global average of 94 point. Philippines were under Indonesia with a score of 118 . This indicates that Indonesia still has high optimism generated by upcoming President's general election, growing middle class and increasing income. However, the inflation that occurred in the last two months has a significant impact for consumers in Indonesia so on quarter three indexes decreased compared with quarter two.

Indonesia itself has become one of the countries with high consumer with various ranges of needs. Indonesia, which has different types of backgrounds, ethnic, racial, religious and other uniqueness cause consumption patterns for one society is different to another. It can be seen from the difference of consumption pattern between male and female especially consumption related to fashion things. Similarly, the consumption pattern of a primary school student will be very different from a college student. College student needs is certainly more complex than elementary school students, in terms of satisfying the needs related to education such as text books, and their living cost are higher than elementary school children if the student is living separately with their parents.

These kinds of consumption patterns are reflected in the consumption pattern of Jakarta society because its population has diverse background. Jakarta consists of various immigrants who came from various regions in Indonesia and immigrants from foreign country, so Jakarta has high level of population diversity. Most immigrants want to have a better job than their homeland as well as for higher education. Therefore, Jakarta can be a proper representation of the consumption patterns of the people of Indonesia. With a population of nearly $10,187,595$ people at the end of 2011, make Jakarta becomes a city with a fairly high level of consumption in Indonesia.

Due to the high level of demand for various types of goods and services and the increasing competition in Jakarta, not infrequently causing more and more producers of goods and services that are trying to provide it in various ways. In providing goods and services that consumers need, manufacturers are willing to perform a variety of fraud and abuse resulting in products that are not quality-oriented. This is certainly become a concern of most consumers in Jakarta, especially in terms of products quality.

Consumers in Jakarta are getting to pay attention about the quality of the products they consume. Sometimes, they gave a positive response or a negative response from the goods and services they consume. Mostly, that so far found in real conditions, consumers will give notice of dissatisfaction from consuming these products. There are many aspects of the complaints by consumers such as about product prices are too high; the lack of quality goods and customer service is not satisfactory.

Most of the complaints on consumer dissatisfaction are only passed from mouth to mouth. This causes most consumers will be affected from the impression of other consumers who have had experience of a purchase of a product, given the psychological characteristics of most Indonesian people are easily given a suggestion or easily influenced by others. Obviously, this incident is something that should be avoided by companies when they try to introduce their products to the public.
This phenomenon is actually not quite good from the consumer side. In Indonesia, consumers' rights are protected by the state and regulated under the Consumer Protection Act (Undang-Undang Perlindungan Konsumen). Complaints on consumer dissatisfaction that is not reported to the authorities will only lead to mere issues without any solving. Referring to the data consumer complaints through Consumer Dispute Settlement Bureau (CDSB/BPSK) Ministry of Trade ${ }^{[15]}$ is still fairly minimal consumer complaints to be brought to justice.

In the second quarter of 2013, there are approximately 1,253 cases of consumer complaints received DSCB and 2,920 complaints through non-governmental consumer protection agencies, only about 721 cases processed Ministry of Trade, while the case is passed to the courts only 15 cases $^{[\mathbf{1 6 ]}}$. This shows that although there is an increase in consumer awareness of the products they consume, the level of consumer awareness of their rights as consumers are still neglected by consumers themselves, as reflected in the low level of complaints by consumers.

Today's phenomenon that occur in these communities maybe caused by the difference of education level of the community. The higher the level of education level of a consumer, then the implication is that consumers will act rationally in consuming the product and care about the products they consume. They already know what their rights to be a consumer when consuming a product and they know that they have protection as a consumer when consuming it. If the consumer feels that the benefit gained from consuming the products below their expectations and it turns out they feel aggrieved, they usually make a complain to the authorities. Consumers, who have low levels of education, may be having different responseswith the consumers who have a higher education level. They can only complain about the quality of the product, pass it onto people without any complaints to the authorities.

This incident implies that most consumers in Jakarta are in fact more concerned about the goods and services they consume, especially in terms of quality. This findings shows that it is still in accordance with the results of the survey conducted by Nielsen international institutions, that the level of consumer confidence in Indonesia, especially in Jakarta is quite high. However, the real action oftheconcernhas not beenrealized inthe realwiththe small numberof consumer complaintsthat go to the court.

\section{Categorization Based on Level of Education and Its Behavior}

\section{1) Primary school}

Primary school students are group of kids who are in the age range 5-12 years. At this time, kids are considered to be very consumptive because they are in growth process. They tend to easily influenced by surroundings about what things they should do, include their purchasing behavior. On the other hand, they are unique because they need less reasons in considering what to buy because kids minds are simple, they will buy everything that attract them the most. Unlike other level of education, they are still straight means they look for what they want, not even consider about lifestyle, social benefit and others.

Regarding to the effective hours of consuming products 
on weekdays, the needs of kids in Jakarta especially are in the range of needs for education, entertainment, and food and beverages. In the morning, at 6 am- $7 \mathrm{am}$, kids tend to watch cartoons at television so that's why firms can take opportunity by promoting kids product at this hour through advertisement and other media. At school, kids usually having break time from 10 am to $11 \mathrm{am}$, when they will have meal time by eating snacks and drinks. Thus, after school kids probably take additional course outside course, so at this hour, business in education sector can gain their own premier hour. Furthermore, usually kids will continue to consume products like snacks and entertainment like watching kids show or cartoons. In addition, products that attract the most for these kids generally have unique packaging because kids tend to choose the products by only looking at its appearance and packaging style.

\section{2) Junior high school}

Junior High School students are a group of teenagers who are in the age range 12-14 years. At this time, teens in this age range are considered to be very consumptive compared with other age groups. Still in their infancy stage, teens in this age also begin to be affected by the environment around them. Most environmental influence on consumption patterns of teens in this age range is the milieu or teenage peer group.

Milieu or teenage peer groups had a significant influence in the formation of a person's consumption patterns especially when they were teenagers. A teenager was always wanted to look cool and up-to-date with emerging trends today. This is because psychologically, the teenagers want their existence to be accepted by teenagers in same age with his/her and showed that these adolescents can adapt well with their surroundings. Though, in fact, growing trend is dynamic and changeable. Therefore, it makes teenagers more consumptive than other consumer groups.

If we analyzed regard to the effective hours of consuming an item on weekdays/school days, the needs of teenagers in Jakarta especially Junior High School student is in the range of needs for technology, entertainment, food and beverages and fashion. If analyzed generally, when teens got up from bed in the morning until they go back to sleep at night, the need for technology will always be the main thing for them. This is because allowing them to communicate and interact with their peers. Moreover, they do not want to fall behind the trend changes occur so that when the trend changes, they can immediately find it out and still on the line with the trend. An example is the use of Blackberry Smartphone which has been rampant among teenagers in Jakarta today, allowing them to still be able to communicate with his/her friends. It would also increase the consumption of pulses provider used. Similarly, teenage Jakarta trend today is social media such as Facebook or Twitter where almost all teenagers have to keep up the trend.

When they were at school on weekdays, especially when they are having break time at 10am - 11am, they will certainly consume foods and snacks that are sold at their school canteen. Considering they are still in its infancy stage, the level of consumption of the food and beverages of course, is still relatively high. At this hour, usually they will be very consumptive for the type of food and beverages they love though, parents of teenagers are still often give them food from home.

When they have finished school, the teenager back home and take a break or doing their homework. After that, at around $4 \mathrm{pm}$ - $8 \mathrm{pm}$ most teenagers are consuming their entertainment needs. Consumption is usually in the form of watching TV shows that most are currently popular teen drama, such as Glee and Teen Soap Opera (as we called Sinetron in Indonesia) or watch shows that are popular among teenagers, such as American Next Top Model. They will try to take the time to be able to watch these shows in order not to fall behind by his/her friends, especially if the TV shows this is becoming a trend and is always discussed when they were together.

If analyzed regard to the effective hours of consuming on the weekend, the needs of Junior High School student in Jakarta is still in the range of need for technology, entertainment, fashion, and food and beverages. When they wake up until they go back to sleep at night, they still consume the need for technologies similarly like on weekdays. Similarly, the need for food and beverages are not much different from when the weekdays. Additional needs of entertainment for teenagers in Jakarta when the weekend is a recreation with family or with peers. This recreation was enumerated by Jakarta teenagers usually at 10 am until drop. This is because this is a period of transition from the children so that they still love to play. Recreation is also experiencing a shift, which is usually when they was younger, they were more like theme parks or interesting objects such as Ancol Beach or Ragunan Zoo, but now when they grow as teenager, they are more like to go recreation to large malls. This is due to the desire of those who always do not want to miss a trend.

Seeing this condition, most companies should be able to see that the consumer in this group, especially in Jakarta, is a huge potential consumer. This is because the consumptive nature of this type of consumer who always makes the trend as a basis for making purchasing decisions. Types of products that can be targeted by the company to meet the needs of consumers in this type (Junior High School Students) is product of technology, food and beverage, fashion and entertainment. Product marketing strategy that may be used by companies to target this consumers is through multimedia such as TV commercials when the TV shows they watched was ended or via Social Media like Facebook or Twitter where most teenagers in Jakarta almost have social networking to communicate with their friends. Therefore, the main strategies that should be applied to companies that target consumers for products of this type is the Brand-storming, which is the company try to create a product that able to adapt to the trend and create a strong brand among consumers despite the trend is changing, but the company can still maintain their existing customers. For example, Starbucks is still a convenient destination for teens to get together in Jakarta, where processed coffee products still become today's teenager's choice, so that we can see Starbucks outlets almost evenly spread throughout the region, especially in the large mall in Jakarta.

\section{3) Senior high school}

Senior high school is level of education where the people 
who are sitting at this are typically begin to enter adulthood, a time when they face the socialization process in a wider environment than Junior High School and certainly more complex. It would also affect the consumption patterns of the person, where their current consumption is affected by lifestyle, technological developments, and tend to follow the changes that occur in their social environment, such as changes in fashion.

In addition, consumption patterns would be affected also by the activities of the person. In Indonesia, the pattern of activity of the people in senior high school in general include; on weekdays, they perform in school activities starting at $8 \mathrm{am}$ until $2 \mathrm{pm}$ or $3 \mathrm{pm}$. After that, they usuallyhang out with their friends, doinggroup assignments, or attend a private tutoring. From the results of our analysis, at $10 \mathrm{am}$ until $11 \mathrm{am}$, usually they have a break time and the products that they consume are mostly snacks. After school about at $2 \mathrm{am}$ or $3 \mathrm{am}$, if they choose to hang out with their friends, they may eat lunch together, and go to places such as restaurants, cafes, malls, or other specified places. If they have to attend private tutoring, means the consumption is education. Whereas, in the weekend, their activities usually include spending time with family at home or recreation area, go with their friends, and shopping.

Looking at the consumption patterns of the people who were in the senior high school, a company should be using multimedia and social media in marketing its product. This case, related to the development of technology and social media that are very influential in senior high school environment. Later, the company should provide products that are able to attract people in senior high school,the product that is able to adapt with the changes in their social environment or in other words a product that is liked by most people in their social environment.

\section{4) College student/undergraduate}

In this modern era, lifestyle factors become one of theessential aspects. Lifestyle is an image for every person wearing it and describes how great the moral values of people in the surrounding community. Or also, the lifestyle is an art cultivated by everyone. Lifestyle is also very closely related to the times and technology. In another sense lifestyle can be a positive influence or a negative for those who run it. Especially student who's studying in the metropolis city.

Average age for college students are above seventeen years old, categorized into adulthood. However, not all of them are mature enough to sort out the influence of the environment. They tend to imitate the today's trend. The dominant mode in community oriented to the western. Ranging from how to dress, how to talk, hangout, how to get along, western music. They could easily imitate, because electronic media and print media featuring the lifestyle many westernized style. As a result, not only in metropolitan communities, but in the countryside too.

College student generally have a more complex pattern of consumption compared to those with primary education, junior high and high school. The following is a general pattern of consumption of students in Jakarta: the range of weekday's time, on $12 \mathrm{pm}-5 \mathrm{pm}$, they usually hangout, and weekends, on 10 am till drop they usually have some recreation, and shopping and also hangout with friends.
They consume lifestyle products, such as fashion, technology, entertainment, and others but in general they want "high quality - low cost product". In this case, the company those have target market of students can play more attractively with the life style inserted into their products. And also companies that have stagnant market share, the best recovery they can do is to sell a life style.

\section{Government's Role}

Role of government in economic activity of a country could be analogous with the head of the household, which the government seeks to stabilize the economic turmoil in the country. Government's goal is to stabilize the national's economy;

1) In order to meet the needs of economic actors (producers, consumers, economy supporting institutions )

2) Build economic system in the form of economic institutional system, legal system, legislation and regulatory policy, management system of government management, economic policy, as well as the distribution system and the development of public infrastructure.

3) Monitor the economic growth.

To achieve these objectives, the government can intervene both active and passive. The purpose of economic development is to achieve the level of prosperity that higher and higher. Government can maintain the reserves accumulation process or capital stock accumulation process with macro-economic planning by setting targets in the development of the real sector, fiscal and monetary. The target is formulated by focus on the economic system, the participation of economic, sources of funding, and the economic policies.

Role of government in a modern economy is divided into:

1) Allocation

1) Basically the resources of a country are limited.

2) The government must determine how much of its resources will be used to produce public goods, and how much will be used to produce individual items.

3) Government must determine from the public goods required its citizens, how much should be provided by the government, and how much that can be supplied by private sector.

\section{2) Distribution}

1) The government should make policies that the allocation of economic resources efficiently implemented.

2) The government should make policies that are well distributed wealth in society, for example through policies:

- Taxation

- Subsidy

- Poverty alleviation

- Income transfers from rich areas to poor areas

- Educational assistance

- Medical assistance, etc.

\section{3) Stabilizing}

1) At today's modern government, almost all countries cede access to the private economy / company. 
2) The government acts as a stabilizer, to keep the economy running normally.

3) Keeping the problems that occurred in one sector of the economy does not spread to other sector.

4) Keeping the favorable economic conditions :

- Inflation under control

- System security is guaranteed

- Legal certainty awake

- Government's Role in the Real.

The role of government in the real sector is going to move potential aggregate demand (aggregate demand) in the community, in order to realize in the form of maintenance production and logistic backup available in the market, covering a minimum of food and clothing needs, electricity, fuel oil chart, and other basic needs of consumers .

In the fiscal sector, the government will make efforts to raise funds from domestic sources primarily through taxation (taxation) is increasing, without making sluggish production and investment activities. While in the monetary sector the government will maintain the money supply (money supply).

The things relating to national economic had been regulated in the Constitution of 1945 section 33, namely:

1) The economy is structured as a joint venture based on kinship principle.

2) Branches of production that are important to the State and welfare of the majority controlled by the state.

3) Earth and water and the natural wealth contained therein controlled by the state and fully used for the prosperity of the people.

4) National Economy is conducted in accordance with the principles of economic democracy, equitable efficiency, sustainability, environmental friendliness, independence, and keep the balance economic progress and national unity

\section{CONCLUSION}

The conclusions from this brief paper is that there are several psychological factors that influence a consumer in making a purchase decision, can be consist of level of education, lifestyle and social class consumers. Then, the level of consumer satisfaction in Indonesia especially Jakarta, is not really high but according to an independent survey by the Nielsen, consumer confidence level in Indonesia is the highest among another country. This is due to consumer dissatisfaction of products quality they consumed that not accompanied by complaints to the authorities. Regarding this condition, the level of education that is being pursued by consumer and his/her daily time will greatly affect their consumption patterns. The higher level of education of a consumer, then consumers will increasingly need more kinds of goods and services, but this is balanced by the attitude of the consumer rationalism in consuming goods. Therefore, the company strategy should also pay attention to psychological aspects, educational level of consumers with their various daily times. By targeting a specific target market by education level consumers, companies can define different but effective strategies for each level.

\section{SUGGESTION}

Suggestion that we submitted on this issue is:

For the company as a provider of goods and services consumed by customers especially in Jakarta, they should set a clear target market first. If we analyzed by level of education that is being taken and the daily time, then the company can target one of these market, consist of elementary school students, junior high school students, high school student and undergraduate students. Then, the marketing strategies applied also different for each target market due to the psychological nature and consumers for each level. In addition, the company must also maintain quality of product at a high level in order to improve customer satisfaction and leads to loyalty by consumers, as well as having a competitive position in the market.

For consumers as users of goods and services, concern and awareness for the quality of the product consumed should be enhanced by providing feedback, criticisms, comments and complaints to the appropriate authorities. It will also have implications on improving customer satisfaction, especially consumers in Jakarta.

\section{REFERENCES}

[1] F. Rangkuti, Measuring Customer Satisfaction, PT Gramedia Pustaka Utama, Jakarta, 2006.

[2] M. R. Solomon, Consumer Behaviour Buying, Having, and Being, $8^{\text {th }}$ edition, New Jersey: Pearson Educations, Inc., 2009.

[3] L. G. Schiffman and L. L. Kanuk, Consumer Behavior, 9th ed., New Jersey: Prentice Hall International, Inc., 2007.

[4] M. Hawkins, Consumer Behaviour: Building Marketing Strategy, $10^{\text {th }}$ edition. New York: McGraw Hill, 2007.

[5] J. C. Mowen and M. Michael, Perilaku Konsumen, Jilid Satu., Edisi Kelima, Jakarta: Erlangga, 2002.

[6] P. Kotler, Marketing Management Analysis, Planning, Implementationand Control, 9th ed., New Jersey: Prentice Hall International, Inc., 1997.

[7] Nielsen. (2013). [Online]. http://www.nielsen.com/us/en/newswire/2013

[8] Consumer Confidence Report. (November 4th 2013). [Online]. Availavle: http:// global-consumer-confidence-reported-slow-butsteady-improvement-.html.

[9] Sindoner News. (November 4th 2013). Konsumen Indonesia Masihbutahak. [Online]. Availavle: http://nasional.sindonews.com/read/2013/05/28/16/743320/konsumen -indonesia-masih-buta-hak.

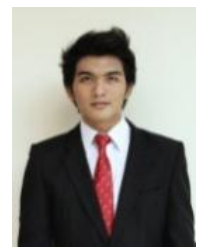

Komang Santhi Arsa was born in Patas, Bali. Now he is being attended lectures at the Faculty of Economic, majoring Accounting in University of Indonesia. Mr. Komang continues to show his potential participating in many competitions, such as Accounting Competition, Economic Olympiad in many different universities in Indonesia, try to grow his own business up, example: Harmony Fashion although still a pilot project. And he active in the organization and many kind committee, now he occupies as head of the Legislation Commission of BPM FEUI, and Vice Chairman of KMHD UI 2013.

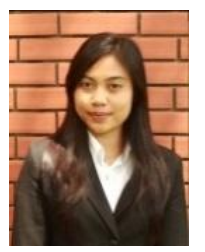

Kadek Ayu Dani Astari was born in Tabanan, Bali. Dani is currently studying at Universitas Indonesia located in Depok, Indonesia and majoring in Accounting Department, Faculty of Economics. She was graduated from SD (Elementary School) No. 4 Dajan Peken in 2005, SMP Negeri (State Junior High School) 1 Tabanan in 2008, and SMA Negeri (State High School) 1 Tabanan in 2011. She active in much kind of organization activities, besides her education. She was an associate of Studi Profesionalisme Akuntan (SPA) FEUI concerning in Student Development Division for period 2012 and she continuously active in Keluarga Mahasiswa Hindu Dharma Universitas Indonesia (KMHD UI) from period 2011 until now. The latest position, she became the Treasure In of KMHD UI 2013. Dani was ever taking internship program in Bank Indonesia, the 
Central Bank of Indonesia, at representative office in Province Bali for period July-August 2013.

Ms. Astari also active in many committees activities. Currently, she is becoming the Treasure In of Tax Seminar and Training (TST) 2014, one of most prestigious Taxation event held by colleges in Indonesia.

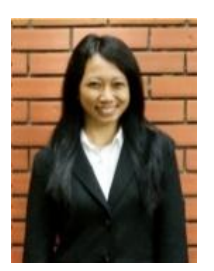

Lovina Claudia Iristianty was born in Tabanan, Bali. Lovina is currently studying at University of Indonesia, the most prestigious university in Indonesia which is located in Depok and now majoring in Accounting Department, Faculty of Economics. She was graduated from Islamic Elementary School in 2005, SMP Negeri (State Junior High School) 1 Tabanan in 2008 and SMA Negeri (State High School) 1 Tabanan in 2011.

She is concerning in many kinds of organization activities beside focusing her education. She was an active member of Studi Profesionalisme Akuntan (SPA) FEUI concerning in Taxation Studies for period 2012 and she was an active scholar from Koperasi Siswa Bangsa for intake 2011. She was ever taking internship program in Bank Indonesia, the Central Bank of Indonesia, at representative office in Province Bali for period July-August 2013.

Ms. Iristianty is also focusing in committees activities. Currently, she occupied is becoming the Project Officer of Tax Seminar and Training 2014, one of most prestigious Taxation event held by colleges in Indonesia.

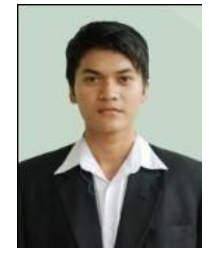

Suhadi Riandana was born in Padang. Suhadi is currently studying at University of Indonesia, the most prestigious university in Indonesia which is located in Depok and now majoring in Accounting Department, Faculty of Economics. He was graduated from Elementary School 6 Padang in 2004, SMP Negeri

(State Junior High School) 1 Padang in 2007 and SMA Negeri (State High School) 5 Padang in 2010. He is active in many kind of organization. He was a member of ICX 3T AIESEC LC-UI for period 2011. He is also a member of UI Model United Nation Club and English Debate Society UI.

Mr. Suhadi is also focusing in committees activities. Currently, he occupied as the chairman of of FEUI Badminton Sports Club. 